\title{
絶縁材料の耐内部部分放電性試験法
}

$\begin{array}{lllll}\text { 正員 加 子 } & \text { 泰 } & \text { 彦 } & \text { (茨城大) } \\ \text { 非会員 渡 辺 } & \text { 茂 } & \text { 隆 } & \text { (茨城大) } \\ \text { 正員東 村 } & & \text { 豊 } & \text { (日 立) }\end{array}$

\section{A New Test Method for Internal Partial Discharge Resistance of Insulating Materials}

Yasuhiko Kako, Member, Shigetaka Watanabe, Non-member (Ibaraki University), Yutaka Higashimura, Member (Hitachi Ltd.)

New test method for internal PD resistance of insulating materials have been studied intensively in the Task Force in CIGRE for over ten years. Recently, the Method II which was developed by authors is now under studying as the international round robin test proposed by domestic Task Force.

This paper describes the new test method concretely and shows some typical test results. This test electrode system is characterized by adhesion of test specimen to the embedded sphere electrode and it may be applicable to all sort of insulating material for the internal PD resistance test under uniform partial discharges. The most important point of this method is to realize the complete adhesion by skillful techniques. It was ascertained that the spread of test data may depend only on the uniformity of materials by this method and the excellent life data can be obtained for some specific materials.

キーワード：試験電極，接着，部分放電，有機絶緑材料，寿命試験

\section{1.まえがき}

絶縁材料の耐内部部分放電性，すなわち絶縁層内部 で発生する部分放電によって絶縁材料が破壊するまで の寿命を評価する試験方法については, 古くから世界 各国で研究が進められ，電気学会においても部分放電 劣化に関する専門委員会がこれまでに幾度か設立さ れ，共同研究が行われてきだ(1)。しかし，まだ標準試 験法を確立するまでには至らず，試験法は劣化メカ二 ズムと共に永遠の研究課題といわれる状況である。 CIGREに扔いては 10 年以上も前に, IECの要請に芯 じて, 試験法開発のための Task Force が発足してお り，国内でもこれに対応する国内 Task Force が発足 し, 精力的な研究が進められてきた。著者らは, 国内 Task Force 発足以来それに参加して共同研究を行う と同時に，1981 年には本墖文に示すような試験電極
装置を考案しその検討結果をCIGREの Task Force 会議で発表してきた ${ }^{(2)}$ 。1983 年には国内 Task Forceにおいて,この方法は標準試験法の候補として 取上げられ，国内の数籄所の研究機関で round robin test が行われてきた。更に国内 Task Forceの提案で この方法が CIGRE において Method II と命名され， 1988 年から国際的な round robin test が行われて いる。

本試験法の電極系は, 試料の組立てが簡単で, 実用 的にはあらゆる材料に適用できることを目指したもの であるが，絶縁破壊を対象とする以上，試料作製に細 心の注意と熟練とを必要とすることも当然である。し かし, 既に国内ではその赛用上の問題点はほほ涩解決さ れ，少なくとも研究用としては実用の段階を迎えてい $3^{(3) \sim(5)}$ 。 本論文においては，著者らがこの電極装置を考案し 
て以来, 各種材料について 1,500 個に及ぶ寿命試験を 行った経験に基づき,この試験法の具体的な方法, 特 長および問題点とその対策などについて述べる。

\section{2. 耐部分放電性試験法}

$\langle 2 \cdot 1\rangle$ 電極系の構成課電寿命試験は, 図 1 に 示すように試験電極系を構成し,シリコーン油中で行 う。以下電極系を構成する具体的な方法を示す。

(1) モールド電極 ベアリング用ステンレス鎆 球 $\left(7 / 32^{\prime \prime}\right)$ を溶剤にて洗浄後, 硬銅管 $(4 \mathrm{~mm} \phi$, 先 端内側面とり）の先端に少量の接着剤（シアノアクリ レート）て接着する。この場合，両者の間に導電性が 維持されることを確認する。次に注型用容器内で電極 を垂直に立てて，あらかじめ減圧脱気したエポキシ樹 脂を注入する。この場合, 注型容器はあらかじめ所定 の硬化温度に保って扔き, 樹脂注入後隇圧脱泡してか ら常圧に扊し加熱硬化させる。このような方法によ り，鋼球と底板の接する部分に硬化に伴うエポキシ樹 脂の「ひ付」（硬化の遲れた部分に発生する表面の凹 み）が発生することを極力防止する。

離型後, 試料を接着させる面を湿式研昰し, 離型昘 を除去する。具体的には電極を固定し，水を含ませた 木綿に研磨用粉末 (平均粒径約 $1 \mu \mathrm{m}$ のアルミナ粉) を付けて手で研磨する。このような研磨により, 球電 極先端は $0.3 \mathrm{~mm} \phi$ 程度露出した状態となる。

（2）試料別途作製した $1 \mathrm{mmt}$ の樹脂板から， 試料中心部に欠樎部が来ないように，場所を選択して 試料を切取る。エポキシ樹脂など注型した材料では， 表面に付着した微量の唯型剂を前項に示した方法で除 去する。

試料表面㧍よびモールド電極表面はエ夕ノールを含 ませた紙ワイパでぬぐい，作業中の污れを除去する。

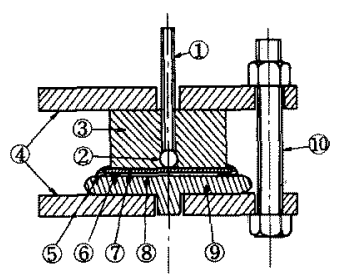

\begin{tabular}{|c|c|}
\hline 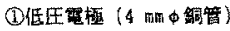 & (6)スペーサ $(0.125 \mathrm{mant}\}$ \\
\hline (2)球醋極 (5.6 的中 SUS) & $(35 \times 45 \mathrm{~mm} \phi \mathrm{PET}$ リン \\
\hline 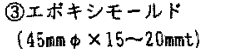 & (7)試料（1mmt） \\
\hline $\begin{array}{l}\text { (45mm } \phi \times 15 \sim 20 \mathrm{~mm} \text { ) } \\
\text { (4)押元板 (FRP) }\end{array}$ & 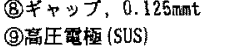 \\
\hline (5)封止エボキシ & (9絶緑ボルト \\
\hline
\end{tabular}

図 1 耐内部部分放電性試験電極の構成

Fig. 1. Test electrode for internal PD resistance.
この場合, 污れの原因は手の油脂および微量のシリコ ーン系異物(油, RTV，䧿型倣など)であるが, エ夕 ノールはシリコーンの完全な溶剤ではないので, 大部 分の污れは溶解しない状態のまま拭取られる。従っ て, 完全は溶郕を用いた場合より, 拭取りの効率は良 く, 污れを除去するために必要な拭取り回数はかなり 少なくてすむ。

（3）接着モールド電極の表面にはシアノアク リレート接若剤（東西合成化学，ボンドアロンアルファ， スーパーセット）のプライマ(スーパー液)を薄く溎布 し乾燥させる。図 2 (a) に示すように, 試料の中央に 2,3 滴のシアノアクリレートを滴下し，(b)，(c) 図に示すようにモールド電極を上から垂直に押付け接 着する。この作業は実際には可動ステージ付小形ボー ル盤を用いると便利である。すなわち，モールド電極 をチャックで固定し，接着剤を試料に滴下して上下関 係の位置決めをした後でモールド電極を押下げて接着 する。ただし，押下げる前にチャックをゆるめて手で 支え，接着面に垂直以外の分力が作用しない上うにす る。硬化後(約 30 秒) 10 15 倍の拡大鏡を用い, 接着 部に微細な気泡のないことを確認する。

試料がポリエチレン系の材料の場合には，図 3 (a) に示すように，少量の弱い接着骩（でんふんん糊など） で試料を, 補助モールド電極に点付け仮接着する。次 に, 試料表面にプライマ（東亜合成化学，アロンポり プライマー）を薄く㳂布し乾煤する。次に，モールド 電極の表面に 2,3 滴のシアノアクリレートを滴下

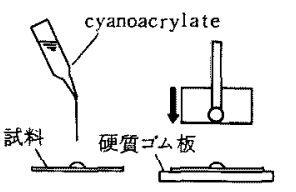

(a) (b)

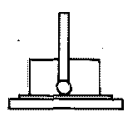

(c)
図 2 モールド電極への試料の接着法 Fig. 2. Adhesion of speciman to molded electrode.

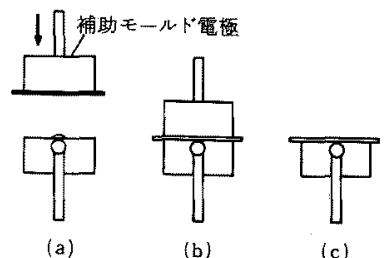

図 3 ポリエチレン系試料の接着法

Fig. 3. Adhesion of polyethylene specimen. 
し，試料を仮付けした補助モールド電極を押下げ， (b)図のように試料と下部モールド電極とを接着させ る。(c)図のように，仮付けされたモールド電極をは く離させ，試料表面の接着剤を拭取る。

（4）平板電極 表面は鏡面研磨とする。毎回 \#2000 のエメリペーパで研磨し再使用する。

（5）組立て 平板電極, モールド電極に接着し

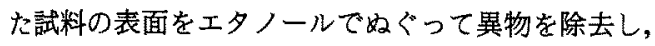
相対湿度約 $20 \%$ 以下に保持したグローブボックス内 に約一昼夜保管し乾㰾する。

乾燥後, グローブボックス内で両電極を $0.125 \mathrm{~mm}$ (5 mil) のポリエステルフィルムのリング状スペーサ を介して重ね，そのまま外部に取出して図1のように 組立てる。その後, 手早くエポキシ系接着剤（コニシ 製，ボンドクイック5）で電極の周りを封止する。

〈2・2〉 モールド電極の再使用材料選定などの 実用試験の場合には，モールド電極は毎回使い捨てを 原則とするが，研究試験の目的には何回も再使用する ほうが経済的である。

これを行うためには，試料板をモールド電極に接着 する際，中央部約 $15 \mathrm{~mm} \phi よ り$ 外側の試料表面にシ リコーン系の䫽型剤をごく薄く塗布しておく。このよ うにしておくと, 寿命試験終了後, 試料とモールド電 極間に $0.1 \mathrm{~mm}$ 程度の薄い鋼板を挿入することで容易 に両者をはく離させることができる。

超小形旋盤〔オーストリア (エムコ社)，万能工作 機ユニマット 3)で球電極周りの樹脂を切削除去し, 研磨洗浄後, $90^{\circ} \mathrm{C}$ に加熱してから図 4 に示すように, デシケータ中で常温硬化の低粘度エポキシ樹脂を $0.2 \sim 0.3 \mathrm{~g}$ 程度滴下し, 手早く減压脱気する。硬化 後, 研磨により余剩の補修用エポキシを除去する。

$\langle 2 • 3\rangle$ 部分放電の測定 寿命試験の場合には図 5 に示すような平衡ブリッジリサジュー図形法 ${ }^{(6)}$ で管 理する。放電が群小化(7)してもりサジュー図形法で測 定する放電の全電荷量にほとんど変化はないが，長時 間の放電で内部が減圧すれば(3)(8)，ギャップの放電維 持電圧の低下, 放電電荷量の増大となって表れる。ま た放電が減少または消滅する原因としては, 試料面上

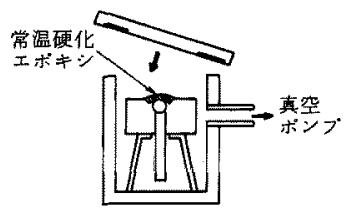

図 4 電極補修部モールド法

Fig. 4. Molding for repair part of electrode.
の放電生成物のたい積, 実験の失敗によるシリコーン 油の流入などがあるが，いずれもこの方法で検出でき る。

〈2:4〉本試験方法の特長 図 6(a), (b)に示 すように, 本方法の電極構成は, 半球棒平板電極系 ${ }^{(9)}$ のそれとほとんど同じで，試料中央部付近の静電界分 布はほぼ同じである。しかし，ギャップで放電が起こ つた状態での電界分布は両者で著しく異なる。すなわ ち, 半球棒平板電極系では試料面上で沿面放電が起こ り，その放電先端部は著しい不平等電界となる。ま た，放電は試料の弱点部を探すかたちでそこに集中し 破壊を引起すために，電極直下部で破壊することはほ とんどない。このことは，たとえ棒電極の周りを本電 極系と同じように絶縁しても，試料が平板電極側にあ る限り同じである。それに対し本電極系では, 印加電 圧によって電極下の放電部の面積は変化するが, 㳂面 放電は起こらず，放電が起こった状態でも試料中の最 大電界部は電極直下である。換言すれば，平等電界中 ての部分放電劣化試験となって招り, 試料に著しい不 整がない限り破壊は電極直下て起こる。

(c)図に示す電極系は, 本方式が CIGREの Task Forceで Method II と命名される以前に Method I

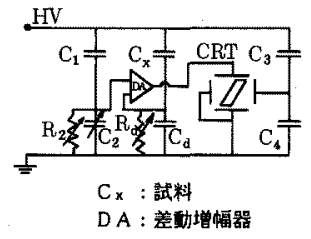

図 5 平衡りサジュー法測定回路 Fig. 5. Measuring circuit of bridgebalanced Lissajous figure.

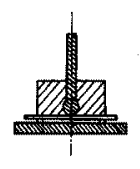

(a)

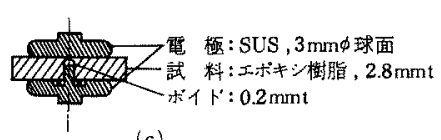

(c)

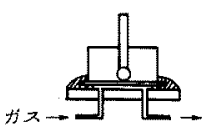

(d)

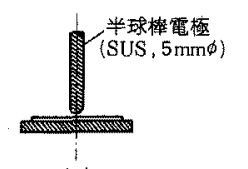

(b)

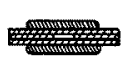

(c)
図 6 各種試験電極の構成

Fig. 6. Arrangement of test electrodes. 
として検討されてきたものである。この方式には数々 の利点はあるが，一般の材料をこのような形に加工す ることは難しく，材料の比較試験用電極としては実用 的ではない。

本試験電極系では，図 6(d)に示すように，通風口 を設けることにより，ボイドに空気の補給が行われる 場合の劣化を模擬することもできるし，また特定のが スを封入して劣化試験を行うこともできる(10)。

更に，図6(e)に示すような中央に穴をあけた絶縁 シートを重枕た, いわゆる三枚重ねの方式(1)でも，柿 イド放電が起こると放電はボイド外周の先端部に集中 し，破壤はほとんどこの部分から起こる。しかも，穴 の周辺部のミクロに見た形状を，各種の材料について 一定に保つことは実用上不可能に近く，その影響は結 局データのばらつきとなって表れる。これに対し，本 方法では放電の集中するような端部はないので，あら ゆる材料を同じ条件で比較することができる。

本試験法を一般化するうえで問題となる点は，試料 を完全にボイドレスに接着する技術であり，電極直下 約 $10 \mathrm{~mm} \phi$ の内部の接着界面に 10 15 倍の拡大鏡て 漸く検知できる程度のはく離部があっても, 寿命は著 しく短くなることを経験的に確加めている。良好な接 着を実現するための管理項目としては，接着すべき面 の微量付着物の完全除去, シアノアクリレートの粘度 管理, 接着圧力のかけ方, すなわち押付け圧力は硬化 が完了するまで一定として変動を与えないことなどで ある。このように，接着には細心の注意が必要である が, 作業自体は熟練すれば比較的簡単である。

ここで，接着の良否の判定法であるが，透明な試料 の場合には既に述べたように，10１5倍の拡大鏡で ボイドのないことを確認すれば十分である。これに対 し, 試料が不透明な場合には現状では直接的な判定方 法はない（大体の様子はモールド電極の背後から見え る)。しかし，透明試料についての経験では，多少の 熟練を必要とすることはもちろんであるが，接着作業 の成功率をほほ $100 \%$ とすることは此較的容易であ る。従って, 少なくとも研究者が行う，以わ研究 試験であるなら，不透明試料に本試験法を適用するの は困難なことではない。

\section{3. 寿命試験データの再現性}

供試エポキシ樹脂板の組成を表 1 に示す。また 50 $\mathrm{Hz} 30 \mathrm{kV}$ の電圧で行った寿命試験の結果をワイブル 確率紙にプロットし，図７に示す。試料板は $\mathrm{A}$ 社か ら3回にわたって供給されたものである。図より明ら かな上うに, デー夕の分布はワイプル確率紙上で二つ
表 1 試料の組成抢よび硬化条件

Table 1. Composition of test sample.

\begin{tabular}{|c|c|c|c|}
\hline \multirow{4}{*}{ 成 } & $\begin{array}{l}\text { 樹 脂 } \\
\end{array}$ & CY 205 & $100 \mathrm{phr}$ \\
\hline & 硬化剂 & HY 905 & $100 \mathrm{phr}$ \\
\hline & 可塑剂 & DY 040 & $9 \mathrm{phr}$ \\
\hline & 促進剂 & DY 061 & $1 \mathrm{phr}$ \\
\hline 硬化条件 & $80^{\circ} \mathrm{C} / 16 \mathrm{l}$ & $\mathrm{ss}+120^{\circ} \mathrm{C}$ & \\
\hline
\end{tabular}

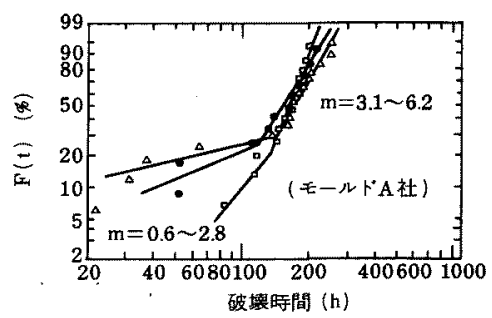

図 7 ロットが異なるエポキシ樹脂の寿命特性 Fig. 7. Life of epoxy resin samples from different lots due to $\mathrm{PD}$.

の直線の組合せとして表すことができる。この場合， 下側の直線は，材質とは直接の関係のない弱点の分布 に対応すると考えられ，ロット間には材質的に有意差 はないとみるのが妥当であろう。

このように数は多くないが，極端に短い寿命のデー 夕が得られるのは, 試料中に存在する弱点の影響と考 えられ, そしてその弱点は, 試料内部に最初から分布 していた欠陷と，試料作製中に高電界部に生じた欠 陌，すなわち接着面の微小はく離などの二種類のもの が考元られる。図 7 の場合，いずれがより大きく影響 したのか明らかではないが, 実験室規模で作製した樹 脂板の均一性が工業製品のそれより劣ることは十分考 えられるし，またこの寿命試験は十分熟練する以前に 行われているので, 接着部の微小欠宿の存在を全く否 定することもできず，恐らく両者の影響がともに表れ たものと考えられる。

同じ組成の試料について，樹脂のロットおよび樹脂 板作製者が異なった場合のデータを図 8 に示す。ここ に, 回帰直線抒よび $90 \%$ 信賴限界は最ゆう法によっ て求めたものである。この場合, 図7の特性とは大き く異なって, 異常に短い寿命のデータはなく,ばらつき は十分小さくなっている(ワイブル分布の形状パラメ 一夕mの值は大きい)。その原因については, いろい ろと考えられるが, 図 7 と図 8 とでは, 試験時期化約 3 年の差があり, 試料用樹脂板坊よび毒命試験用試料 の作製技術が向上したことが主要原因と考えられる。 ただし，同じ銘柄の材料を用いても $A, B$ 両社で作製 


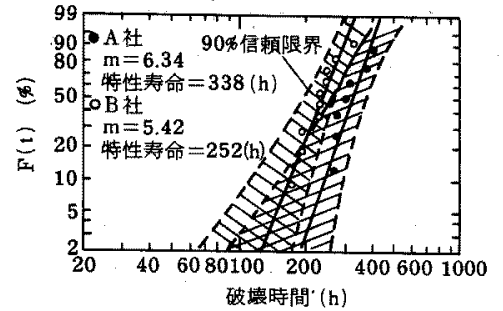

図 8 試料作製者の異なるエポキシ樹脂の 寿命特性

Fig. 8. Life of epoxy resin samples from different sources.

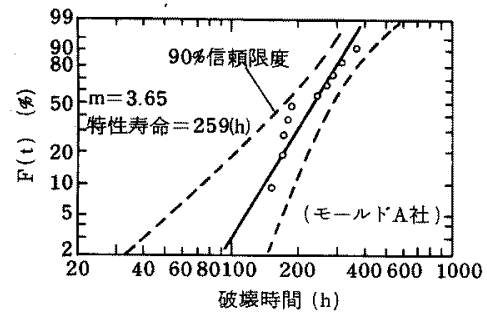

図 9 可塑剤なしエポキシ樹脂の寿命特性

Fig. 9. Life of epoxy resin without plasticizer.

した試料の寿命平均値に差のあること，および同じ $A$ 社で作製した試料でも時期によって寿命に差が出 たことについては原因は明らかではない。しかし， 90\%信頼限界もかなり重なっているように，その差は 奏用的に重要な意味をもつほどではない。

表 1 に示す標準組成から，可塑剂 DY-040を除い た組成の樹脂板について，寿命試験の結果を図 9 に示 す。ばらつきは図 7 よりやや大きくなっているが，実 用上十分な再現性は得られている。また樹脂板作製者 および作製時期の等しい図 8 の Aのデー夕と比べれ ば，平均若命は短くなっているが，樹脂板作製者の異 なる図 8 の Bのデータと比較すれば，平均寿命に差 はなく，実用的には，可塑剂 DY-040の影響はほと んどないといえる。

次に，ポリエチレンについての寿命試験の結果を図 10 に示す。この場合, 低密度ポリエチレン〔宇部興 産, Z-265, $d$ (密度 $)=0.92$ ) 扔よび高密度ポリエチレ ン（昭和油化，ショウレックス $5003, d=0.945$ ) は ともにペレットの状態で入手したもので，樹脂板作製 (ロール練りおよびヒートプレス) 㤌実験室で行った。 ポリエチレンは完全な透明でないため，接着部の微細 欠宿の有無を直接確認することはできないが，実験室 で少量作製した試料板に高度の均一性が期待できない

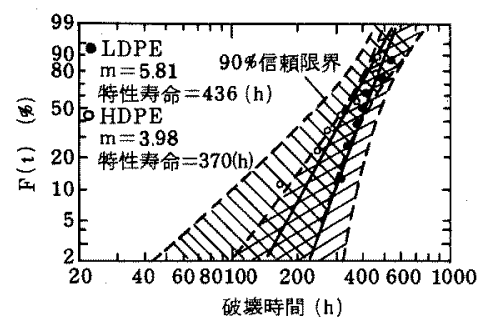

図 10 ポリエチレンの寿命特性

Fig. 10. Life of polyethylene.

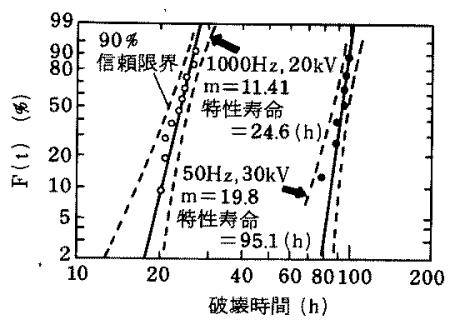

园 11 PMMA の寿命特性

Fig. 11. Life of PMMA.

にもかかわらず，結果としては十分小さいばらつきの データが得られている。従って，この場合接着部には 欠宿はほとんどなかったものと考光られる。なお，低 密度ポリエチレンのほうがやや寿命が長い結果となっ ているが，実用的に意味のあるほどの差ではない。

以上の実験では, 試料の厚さはいずれも 1.0 $\pm 0.05 \mathrm{~mm}$ に管理されており, 平衡りサジュー法で 測定した放電電流はエポキシの場合 7.5-9.5 $\times 10^{-7}$ $\mathrm{A} の$ 範囲, ポリエチレンの場合 $5.5-7.0 \times 10^{-7} \mathrm{~A} の$ 範囲であったが，時間と共に隇少傾向を示すもの，不 変のものなど様々であった。しかし，この範囲内では 寿命と試料厚さおよび放電電流との間に明確な対応は 見られなかった。

次に，絶縁に実用される材料ではないが，材質の均 一性抢よび高い寸法精度の試料板が容易に得られるも のとして，アクリル樹脂板（日東樹脂工業, CLAR EX) について寿命試験を行ってみた。結果を図 11 に 示す。図より明らかなよに, $50 \mathrm{~Hz}$ 電圧, $1,000 \mathrm{~Hz}$ 電压いずれの場合にもデータのばらつきは著しく小さ く,これは破壊を対象とした寿命試験では期待し得る 最高レベルの再現性であると考えられる。すなわ方， 本試験法においては，試料作製が正常に行われている 限り，データのばらつきは主として材料自体の不均質 性に起因し，接着など試料の作製条件などの影響は極 めて小さいものと考えられる。 
このことから逆に，アクリル樹脂板は耐内部部分放 電性試験の試料作製技術のレベルをチェックする標準 材料として有用と考えられ，このことは既に国内の Task Force の意見として, CIGREに提案されてい る。

以上に示したように，試料の作成技術が向上すれば データのばらつきは減少するが，一般にばらつきの原 因は多種多様であり，それを解明するためには，寿命 データのみでなく，あらゆる情報を総合することが必 要である。しかし，そのような研究試験とは別に，本 試験法を標準試験法とする場合には, 得られたデー夕 を評価する方法を決めておくことが必要である。常識 的には上限, 下限の例外値を除去することが考えられ るが,これについては現在 CIGREの Task Force で 検討されているので, その結論を待ちたい。

高周波電圧による劣化の加速倍数については, 著者 らは同一電圧で周波数のみ異なるという条件で比較試 験を行っていないので, 明確に示すことはできない が, CIGRE の国内 Task Forceにおける検討結果を 見ると, $1,000 \mathrm{~Hz}$ 程度までは周波数に比例した加速 関係が成立していることがわかる。もちろん, 実用的 な材料の比較試験のためには, 現象の等価性が成立 し，ほほ周波数に比例して劣化を加速できれば十分で あり, 著者らは効率的な研究を進めるために, 現在, $1,000 \mathrm{~Hz}, 20 \mathrm{kV}$ 印加を標準の試験条件としている。

\section{4. むすび}

以上述べてきたように，本試験法によれば，再現性 の優れたデータを得ることができ, 更にこの方法はあ らゆる材料に適用でき, 容易に材料の比較試験ができ るという点からみて, 実用性は極めて高いと考えられ る。もちろん, 特定の材料を対象とするとか, 特定な 使用条件の模擬が目的であるなら，また別な方法が考 えられるのは当然である。本方法は既にCIGREにお いて, 国際的にも評価が得られているが, まだIEC が標準試験法の候補として取上げる段階には至ってい ない。標準試験法となると考慮すべきことが多いが, 本試験法の基本的な問題点は, 最も高電界となる部分 を接着していることである。既に述べたように，本試 験法のすべての特長は試料をそのように接着すること で得られているが, それだけに接着は完全であること が必要で, その部分の欠陥は致命的となる。従って, この接着には当然ある程度の熟練が必要であるが，一 方, 一度要領を会得すれば作業自体は簡単である。我 が国のように，少なくとも研究の初期段階には，研究 者自身が直接試料を作製して実験するというようなシ
ステムの下では，この問題の解決も比較的容易である が，そうでない場合には，必要な技術レベルに達する のにかなりの時間がかかることになろう。著者らとし ては, 今後はこの方法を活用し, 材料の開発研究を進 めたいと考えている。

終りに, 本試験法を CIGRE の国内 Task Force の round robin test の対象として取上げられ, 研究の取 りまとめと, CIGRE の場で国際的な研究として発展 させることについて, 優れた指導力を発揮され, 同時 に, 著者らに対し数々の御指導および御助言を睗つ た, CIGRE 国内委員会 SC-15(絶縁材料)分科会前委 員長 家田正之博士 (名古屋大学名誉教授), 現委員長 田中祀捷博士（電力中央研究所）に厚くお礼申し上げ ると共に, 有益な御討論をいただいた CIGRE 国内 Task Forceの委員各位に感謝申し上げる。

(平成 3 年 1 月 7 日受付)

\section{文献}

（1）電気学会技術報告：「絶縁材料の部分放電（コロナ）による 劣化 [IV] J, (II 部) No. 43 (昭 51)

(2) W. R. Kodoll, et al.: "Internal Partial Discharge Resistivity Testing", CIGRE 15-04 (1988)

（3）北村・涉谷・平林：「エポキシ樹脂と金属電極界面における 密閉ボイドでの窒化物の生成と減圧現象」, 電学論 A, 107, 225 (昭 62-5)

（4）岩田・梅本：「絶縁材料の部分放電寿命特性」, 昭 62 電気学 会全大, No. 336

（5）加子・渡辺：「各種絶縁材料の内部部分放電劣化による 寿命 特性」, 昭 62 同上, No. 335

（6）井関・竜田：「リサジュー図形からみた部分放電の特性と機 構」, 第 17 回絶材シンポジウム, P-10, 205 (昭 59)

(7). 北村・平林：「エポキシ樹脂における内部部分放電の経時変 化」, 䉓学論 $A, 103,47$ (昭 58-9)

（8）加子・東村：「エポキシ樹脂の内部部分放電によるボイド内 ガス圧及びポイド内表面抵抗の変化」, 同上 A, 105, 555 (昭 60-10)

（9）電気学会技報:「絶縁材料のコロナ放電による劣化 [II] 」, ( I 部), No. 90 (昭 44)

（10）加子・渡辺：「添加㘊による内部部分放䨋劣化抑制効果の経 時変化」, 平元電気学会全大, No. 278

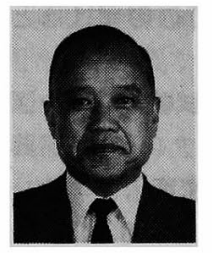

\section{加子 泰 彦 (正員)}

昭和 3 年 7 月 27 日生。 27 年 3 月 京都大学工学部電気工学科卒業。同 年 4 月 (株) 日立製作所入社。日立研 究所にて高電圧絶緑の研究に従事。 41 年同所第二部主任研究員, 46 年第二部部長。 58 年 6 月同社退職。同年 7 月茨城大学工業短期大学部電気 工学科教授, 平成 2 年 10 月同工学部電気電子工学科 教授。工学博士。平成元年 4 月電気学会茨城支所長。 58 年電気学会論文賞受賞。 


\section{渡 辺 茂 隆（非会員）}

昭和 2 年 4 月 29 日生。 27 年 3 月 東北大学理学部化学科卒業。同年 (株) 日立製作所入社。31 年 10 月日 立電線(株)の分離独立に伴い同社に 転属。 55 年技師長, 57 年 7 月茨城大学工業短期大学 部工業化学科教授, 平成 2 年 10 月同工学部システム 工学科教授, 現在に至る。理学博士。高分子材料の物 性に関する研究, 電気絶緑材料の研究および開発に従 事。36 年ポリサーグランプリ受賞。37年日本ゴム協 会優秀報文賞受賞。

\section{東 村 豊 (正員)}

昭和 21 年 9 月 5 日生。 45 年 3 月 京都工芸繊維大学卒業。同年 4 月 (株) 日立製作所入社。以来，同社日 立研究所において, 電力機器絶縁の 研究開発に従事。現在, 同所主任研究員。 